Please do not remove this page

RMIT

UNIVERSITY

\title{
How environmental regulations affect innovation in the Australian oil and gas industry: Going beyond the Porter Hypothesis
}

Ford, Jerad; Steen, John; Verreynne, Martie-Louise

https://researchrepository.rmit.edu.au/esploro/outputs/9921861327401341/filesAndLinks?institution=61RMIT_INST\&index=null

Ford, J., Steen, J., \& Verreynne, M.-L. (2014). How environmental regulations affect innovation in the Australian oil and gas industry: Going beyond the Porter Hypothesis. Journal of Cleaner Production, 84(1), 204-213. https://doi.org/10.1016/j.jclepro.2013.12.062

Document Version: Accepted Manuscript

Published Version: https://doi.org/10.1016/j.jclepro.2013.12.062

Repository homepage: https://researchrepository.rmit.edu.au

CC BY-NC-ND V4.0

(C) 2013 Elsevier Ltd. All rights reserved.

Downloaded On 2023/04/26 11:37:39 +1000 
How Environmental Regulations affect Innovation in the Australian Oil and Gas Industry: Going beyond the Porter Hypothesis

Corresponding author:

Jerad A Ford

Affiliation: UQ Business School, University of Queensland St Lucia, Australia

Email: j.ford@,business.uq.edu.au

Phone +61403141513

Address: Blair Drive, St. Lucia, QLD, 4172

Co-Authors:

John Steen

Affiliation: UQ Business School, University of Queensland St Lucia, Australia

Email: j.steen@business.uq.edu.au

Martie-Louise Verreynne

Affiliation: UQ Business School, University of Queensland St Lucia, Australia Email: m.verreynne@,business.uq.edu.au 


\begin{abstract}
The impact of environmental regulation on innovation is of central interest to many industries and policy makers alike. While traditional research adopts a top-down view of regulation and attempts to measure the innovation response, the more bottom-up view of contemporary theory argues that firms produce innovations that exceed compliance levels as a competitive strategy. We approach this dichotomy by investigating innovation introduced by Australian oil and gas firms in light of environmental regulatory compliance burden and firm-level characteristics, including competitive capabilities. Analyses of survey responses, executivelevel interviews and conference proceedings reveal both regulatory (top-down) and competitive advantage (bottom-up) perspectives explain innovation in this industry. Regression analyses reveal that product/service and novel innovations (all types) are related to a high compliance burden, competitive skills, research and development activity, and engagement in formal collaborations. Interview and conference data add nuance to our findings revealing collaborative compliance frameworks result in similar innovation outcomes.
\end{abstract}

\title{
Keywords
}

Environmental regulation, innovation, oil and gas 


\section{Introduction}

The Australian oil and gas industry is undergoing a period of rapid growth. Nearly \$US 350 billion of gas projects are underway or in various stages of planning in the conventional and unconventional (e.g. coal-seam gas) space (BCA, 2012; Rennie, 2013). These projects have considerable interface with the environment due to their scope and scale (Scott et al., 2011). For instance, the coal-seam gas (CSG) to Liquified Natural gas (LNG) projects in Queensland will require thousands of kilometers of buried transportation pipelines connecting thousands of geographically dispersed wells to centralised LNG production facilities (ABC, 2012). At present, the Australian oil and gas industry provides a unique opportunity to assess the impact of environmental regulation on firms operating in this environment and in particular, how regulation affects innovation. Our paper therefore poses the question: How does environmental regulation relate to the introduction of innovation in Australian oil and gas firms?

The starting point of this investigation is Porter's (1991) hypothesis that environmental regulation spurs innovation. However, we broaden this narrow 'stimulusresponse' perspective (Ambec et al., 2011) by including firm-level factors of competitiveness and collaboration. We include competitive aspects because current theorising suggests firms over-comply with regulations in the development of innovations to maintain competitive advantage, rather than being driven by regulation (Berkhout, 2014; Sarker, 2013). This is because over-compliance helps to shape the nature of future regulation (and therefore the competitive landscape) and shores up 'social license' to operate by anticipating the needs of social stakeholders thereby ensuring long-term viability of the enterprise (Berkhout, 2014; Gunningham et al., 2004; Wu, 2009). We include collaborative aspects because we recognise that the networks of firms operating in particular industries manage the impact of regulation and create innovation (Gann and Salter, 2000; Kemp et al., 2000).

We base our analysis on a representative cross-section of the entire supply chain of the Australian upstream oil and gas (exploration and production) industry. This unique data set enables us to develop and test regression models to understand the relationship of environmental regulation with several types of innovation introduced at the firm level. These models also include 'competitive advantage' constructs and other variables that investigate the capability to deal with, and the propensity to over-comply with, regulations at the firm level. To contextualise our findings, particularly the specific nature of environmental regulations affecting firms, we present five cases of innovation within the CSG industry in Queensland, Australia. 
Our paper makes three main contributions that together show the relationship between regulation and innovation is complex and multi-level. First, we find some support for the original version of Porter Hypothesis and the traditional top-down view of regulation. Our models reveal that environmental regulatory burden relates strongly to product and service innovations as well as all types of novel innovations. Second, we find some contextual support that collaborative regulatory schemes relate to these same types of innovation from our examples in the CSG industry. Third and most important, we contribute empirical evidence that these innovation types are strongly related to firm-level competitive differentiators, research and development $(\mathrm{R} \& \mathrm{D})$ activity and formal collaboration with other firms. We posit the relationship with capabilities reflects the propensity of firms to go beyond compliance as a competitive strategy and to maintain social licence to operate (Berkhout, 2014; Innes and Bial, 2002; Sarker, 2013; Wu 2009). We postulate the importance of collaboration indicates network effects relating to the entire supply chain organising in response to regulation and produce innovation (Gann and Salter, 2000; Kemp et. al., 2000).

The remainder of this paper is organised as follows. First, a review of the broader literature on innovation as a response to environmental regulation, in the vein of Porter (1991) and Porter and Van der Linde (1995), reveals reliance on proxy measures and an equivocal set of findings. There we also review more recent research on why firms go beyond compliance as a competitive strategy to buttress the long-term viability of the firm. Second, the research methods section describes the quantitative approach of the paper. There we discuss the survey, exploratory factor analysis, the variables included in the models and the logistic regression procedures. This section also describes the collection of qualitative data in the form of a purposeful sample of executive interviews and conference proceedings that help illustrate the quantitative findings. Third, the analysis and discussion section presents the models and explores the findings through illustrative case examples. Finally, the conclusion section summarises our findings and contributions and explains the theoretical and practical implications of our findings.

\section{Literature Review}

\subsection{Early views on regulatory response}

Economists view regulation as a necessary response to account for the absence of a market for environmental impact (Jaffe et al., 2005). In the traditional view there are two general categories of policy instrument for inhibiting environmental degradation: market 
based approaches and 'command and control' standards (Popp et al., 2009). Market based mechanisms, such as emissions trading, allow firms to determine the best way to become more efficient (Lange and Bellas, 2005; Newell et al., 1999; Wu, 2009). 'Command and control' regulation prescribes processes and technology to meet specific environmental targets (Managi et al., 2005; Purvis and Outlaw, 1995).

Early on it was argued that policing and implementing regulations was inefficient, costly and can erode competitive advantage. The argument was progressed that regulation is an additional cost to firms and erodes opportunities for increased business performance, and is thought to confer advantage to firms that operate under less stringent regulations (Freeman and Haveman, 1972). In this traditional view of regulation, firms would only choose to exceed regulation if there were financial benefits of doing so (Gunningham et al., 2004; Porter and van der Linde, 1995).

Porter (1991), in an article published in Scientific American, claimed that environmental regulation spurs innovation and that this innovation can outweigh the costs of compliance and provide benefits. Many efforts have been undertaken to test the so-called 'Porter Hypothesis', delivering mixed results and leaving a swath of conflicting evidence to inform managers and policy makers. For instance, some evidence supports the relationship between regulation and innovation (Lanjouw and Mody, 1996), while other studies find no connection to either (Jaffe and Palmer, 1997). A study on German manufacturing showed no evidence that the intense existing regulatory structure impeded firms ability to compete internationally (Triebswetter and Hitchens, 2005). Some studies find intense regulation is related to increased productivity in turn explained by adoption of technology (Berman and Bui, 2001), and yet others find that environmental regulation only slightly contributes to overall productivity declines (Christainsen and Haveman, 1981).

Many justifications exist to explain the difficulty in finding clear relationships between regulation, innovation and performance. As Porter and van der Linde recognise, "Innovation cannot always completely offset the cost of compliance, especially in the short term before learning can reduce the cost of innovation based solutions" (Porter and van der Linde, 1995, p.100). Other difficulties in observing such relationships have to do with the sometimes lengthy time frames associated with innovation and the time it takes to diffuse and be adopted, which creates ambiguity in measurement (Popp et al., 2009). Another issue contributing to ambiguity is the extensive use of industry level proxies like patents (Brunnermeier and Cohen, 2003; Hascic et al., 2008; Popp, 2006). 
The type of regulation itself has been shown to promote or inhibit innovation, but this too has led to conflicting findings. 'Command and control' regulation is thought to disincentivise new innovation development because of its focus on specific technology and minimum standards (Managi et al., 2005; Purvis and Outlaw, 1995). While innovation is induced by prescriptive regulation, unless properly designed it lacks incentives for further innovation (Yabar et al., 2013). For instance, Managi, Opaluch, Jin and Grigalunas (2005) found that in the US offshore oil and gas industry, the inflexibility of the "command and control' environment was related to a lag in environmental performance, and encouraged serial adoption of technology from other industries. Market based mechanisms in contrast are thought to promote innovation by allowing firms to determine the best methods to achieve compliance (Lange and Bellas, 2005; Newell et al., 1999; Wu, 2009). However, Sharma (2001) studied the difference between 'command and control' style regulations and more flexible environmental regulations on innovation between the US and Canadian oil and gas industries and found no significant difference in the outcome for environmental performance.

The conflicting evidence of the relationship between regulation and innovation calls for alternative perspectives that include other explanatory factors, including those at the firm level.

\subsection{Beyond compliance and the role of the firm}

The traditional top-down view of regulation is becoming secondary to the notion that firms regularly exceed compliance for reasons related to social license, and this is a primary mechanism that spurs innovation at the firm-level (Berkhout, 2014; Gunningham et. al., 2004; Sarker, 2013). The concept of social license stems from increasing consumer awareness and proliferation of influential stakeholder groups that exert influence beyond the traditional governmental roles (Berkhout, 2014). Neglecting social concerns has drastic negative impacts on performance. Monsanto's failure to address the concerns with genetically modified food in Europe led to an erosion of trust, and necessitated a rebranding of the corporation. Similarly, Nike's perceived exploitation of labour in developing countries directly impacted the firm and lead to a damage of the brand (Gunningham et al., 2004).

Thus, firms now realise that they must maintain social license to operate and are increasingly undertaking efforts to do so (Berkhout, 2014; Pellegrino and Lodhia, 2012; Sarker, 2013). To do this they must proactively anticipate the social acceptableness of products, even to the point where in some circumstances this is unprofitable (Gunningham et al., 2004). This is in an effort to maintain good public reputation, and to inculcate strong 
community relationships that support future viability of the enterprise (Sharma, 2001). This strategic commitment to sustainability means that subsequent innovations are responsive and proactive to social and environmental needs, in turn helping ensure long-term viability of the firm (Berkhout, 2014). Evidence from the construction industry reveals managerial concern as the most significant driver for adoption of green practices. Stakeholders pressures do not seem to influence adoption at all and regulations only appear significant driver for large firms (Qi et al., 2010).

Further, going beyond compliance can shape the regulatory landscape, influencing the progression of regulation as a risk reduction strategy (Berkhout, 2014). For example, mining and oil and gas trade-groups are developing voluntary codes of conduct relating to social and environmental regulations (Sarker, 2013b). The Australian Petroleum Production and Exploration Association's (APPEA) code of conduct endorses voluntary behaviors regarding continuous improvement of health safety and environmental performance (APPEA, 2013: Sarker, 2013). Such codes of conduct can arguably preempt the promulgation of more formal 'command and control' regulation (Sarker, 2013).

Beyond maintaining social license as a risk reduction strategy, over-compliance is quickly becoming recognised as a major source of competitive advantage (Berkhout, 2014). Indeed, voluntary norms around environmental regulation have been shown to spur managers into pursuing proactive environmental management strategies leading to competitive advantage, an effect not seen with command and control regulations (López-Gamero et al., 2010). Exceeding compliance contributes to firms' competitive positioning, ensuring that the firm maintains a continual pipeline of differentiated products that do not have inherent environmental limitations ( $\mathrm{Wu}, 2009)$. Over-compliance helps shape the future regulatory landscape for the competition (Berkhout, 2014; Sarker 2013, Wu, 2009). When firms raise environmental performance benchmarks for products, it may prompt regulators toward stricter compliance regimes creating new benchmarks for their competitors, and may represent barriers to entry (Innes and Bial, 2002).

\subsection{Expectations for Australian oil and gas regulation and innovation}

The literature review reveals that top-down regulation plays an ambiguous role in the innovation process, although it seems that less-prescriptive regulation can perhaps spur more innovation than 'command and control' strategies. Variability in the industries studied and the methods used undoubtedly contributes to this ambiguity. In contrast, there is more recent and compelling theory that firms are now exceeding compliance in order to use it as a 
competitive strategy and to ensure long-term viability (Berkhout, 2014; López-Gamero et al., 2010; Sarker, 2013; Wu, 2009). Thus the combination of regulation (top-down) and firmlevel strategy (bottom-up) appears to be the most accurate means to investigate how firms within particular industries innovate with regard to the environment (Sarker, 2013).

As such, first we anticipate that existing regulations will have a positive effect on innovation in a basic view of the Porter Hypothesis (Porter, 1991; Porter and Van der Linde, 1995). This can be measured by using survey data on perceived environmental regulatory burden at the firm level. Second, we anticipate that the innovative response is even stronger if the regulation is developed in conjunction between industry and regulators (Harrison, 2002, 1999; Sarker, 2013b), or at least more collaborative and less-prescriptive in nature (Lange and Bellas, 2005; Newell et al., 1999; Wu, 2009) since this allows for the development of more creative solutions. Since we cannot observe this second form of innovation response directly from our survey data, this notion is explored using case examples.

Third and most importantly, in line with current theory, we expect that the industry will innovate because of the high stakes associated with losing social license (Sarker, 2013). Therefore we postulate innovation will be strongly related to firms that have higher levels of competitive capabilities (Berkhout, 2014; Gunningham et. al., 2004; Sarker, 2013) including those that conduct $\mathrm{R} \& \mathrm{D}$, as well as being more prevalent in firms that pursue formal interorganisational collaboration (Gann and Salter, 2000; Kemp et. al., 2000).

\section{Research Method}

A survey instrument was used to capture data from firms operating in the oil and gas industry of Australia. After exploring descriptive data and correlations, we conducted exploratory factor analyses and logistic regressions using IBM SPSS Statistics 19. Logistic regressions based upon Maximum Likelihood Estimating (MLE) techniques were employed. In total we explored four regression models with various groups of innovation types (Damanpour, 1991). Qualitative data from primary and public sources are employed to discuss and provide illustrative support for the findings of the models. The following sections expand on this approach.

The use of primary data in this paper is governed by The University of Queensland's ethics approval process. 


\subsection{Survey}

Data were collected using a well-tested innovation survey instrument (Cosh et al., 2012) that is based on internationally recognised set of innovation and collaboration measures (OECD, 2005). The survey was administered by phone to the executive level membership of APPEA.

We address selection bias in two ways, first by comparing the sample to the sample frame, and second through a t-test of means between early and late responders. On the first point our sample represents over a quarter of the actual population and accurately reflects the industry profile. We know this because our survey targeted the membership of the leading industry trade group which claims to represent 98 per cent of the firms operating the upstream oil and gas industry in Australia (APPEA, 2013). Of the 290 firms targeted, 27.6 per cent responded, which is on par with executive-level response rates in business research (Baruch, 1999). In addition proportions of our sample, in terms of the number of oil and gas operators versus all others, are nearly identical to the sample frame (Table 1).

On the second point, we conducted an independent samples t-test of means (twotailed) using the variables from our models by splitting the sample into early and late responses (mid-point of a 39-day collection campaign) (de Villiers et al., 2010). The only significant difference we found was in the industry control variable 'SERVICE'. This was anticipated since we prioritised the oil and gas operator firms because of expected difficulty in accessing their executives. Despite this known bias in our sample collection method, there is still no significant mean differences in the variables of interest between groups. For these reasons we feel strongly that selection bias is not a concern.

Table 1- Representativeness of sample

\begin{tabular}{llclc}
\hline Type & \multicolumn{2}{c}{ Sample obtained } & \multicolumn{2}{c}{ Sample Frame } \\
& No. & per cent & No. & per cent \\
\hline Operators & 25 & $\mathbf{3 1}$ & 94 & $\mathbf{3 2}$ \\
All others & 55 & $\mathbf{6 9}$ & 203 & $\mathbf{6 8}$ \\
\hline & 80 & 100 & 297 & 100
\end{tabular}

In addition to the standard variables usually obtained from this type of survey (see Table 2), the instrument was expanded to include several industry-specific contextual factors. First, key differentiators for 'competitive advantage' were rated on a Likert scale (Table 3). Second, regulatory factors that served as limitations to reaching business objectives were also rated on a five point Likert scale as listed in Table 3. 


\subsection{Variables}

\subsubsection{Dependent variables}

Our survey enquired about the introduction of six innovation types during the past three years. We also asked if these types of innovation were new-to-the-firm or new-to-the-firm and industry.

Table 2 - Innovation types measured in survey, introduced in prior three years

\begin{tabular}{ll}
\hline Innovation & Description \\
\hline Product & Technologically new or significantly improved physical product / technology \\
Process & Technologically new or significantly improved methods of producing a physical product / technology \\
Distribution & $\begin{array}{l}\text { Technological improvements in supply, storage or distribution systems for physical product / } \\
\text { technology }\end{array}$ \\
Service & New or significantly improved 'service product' \\
Service Delivery & New method to produce and deliver your 'service product' \\
Managerial & New organisational/managerial processes or marketing methods \\
\hline
\end{tabular}

We consolidated the innovation types into four dichotomous dependent variables (Table 4). The first two variables, NOVEL and INCREMENTAL, indicate varying degrees of novelty. The NOVEL variable indicates that the firm had at least one innovation (of the types listed in Table 2) that was both new-to-the-firm and new-to-the-industry. INCREMENTAL innovations indicate at least one innovation was only new-to-the-firm (and not to the industry) (Köhler et al., 2012). We also created the variable PRODSERV that indicates the presence of either a product or a service innovation (any degree of novelty). Similarly we also created the PROC variable that relates to the internal processes of the firms indicating the presence of any distribution, process, service delivery or managerial innovations (any degree of novelty) (Damanpour, 1991).

\subsubsection{Independent variables}

First, we selected three independent variables from our survey that related directly to regulatory issues: government regulations and compliance (red-tape) termed RED; environmental compliance (green-tape) termed GREEN and environmental regulatory uncertainty termed UNCERT. Firms were asked whether each "acted as a significant limitation or barrier on your ability to meet your business objectives.” Each variable was transformed into a binary variable by assigning a ' 1 ' to the Likert scale responses of four and above (4 - Very Significant Limitation and 5 - Crucial limitation) and ' 0 ' to the other responses.

Second, we developed constructs for competitive advantage in an effort explore the notion that environmental innovation is a competitive strategy (Berkhout, 2014; Sarker, 2013; 
$\mathrm{Wu}, 2009)$. Using exploratory factor analysis (EFA) with Varimax rotation, we revealed two latent constructs for competitive advantage based upon questions regarding firms' "key differentiators". One major construct emerged (Table 3), which we termed "STANDING" and that relates to firms' ability to maintain reputation, breadth and depth of expertise and provide consistent project execution success. STANDING has a Cronbach alpha of .811 . Another latent key differentiator construct we termed "NETWORKING", and it has a Cronbach alpha of .680. These were both within the range suggested by (Hair et. al., 1998). The NETWORKING construct relates to the partnership network firms maintain and the ability to leverage those networks into new products and services.

\section{Table 3- EFA for competitive advantage constructs}

\begin{tabular}{|c|c|c|c|}
\hline \multicolumn{4}{|c|}{ Rotated Component Matrix ${ }^{a}$} \\
\hline & \multicolumn{3}{|c|}{ Component } \\
\hline & Standing & Networking & Operations \\
\hline Range of expertise/products/services/technology & .855 & & \\
\hline Established reputation & .769 & & \\
\hline Specialised expertise/product/service/technology & .764 & & \\
\hline Ability to execute on projects in a timely manner & .701 & & \\
\hline Marketing and promotion skills & & .838 & \\
\hline Partner network \& related arrangements & & .793 & \\
\hline $\begin{array}{l}\text { Stakeholder management (e.g. soliciting and actively managing } \\
\text { feedback, across project life cycle) }\end{array}$ & & .565 & \\
\hline Health, Safety, Security and Environmental record & & & .887 \\
\hline Supply chain management and integration & & & .681 \\
\hline
\end{tabular}

Third, due to the collaborative nature of the industry, we employed the variable COLLAB which measures whether or not the firm participated in any formal collaboration. We sharpened the definition of collaboration to that which is beyond the normal day-to-day operations of the firm that is intended to improving some aspect of the business. A summary of the variables used in the modelling is shown in Table 4.

\subsubsection{Controls}

Control variables included the conduct of R\&D and the industry control of SERVICE that relates to firms that are not oil and gas operators. We also included the natural logarithm of size (LOG_SIZE) measured by the number of full time staff. The log-transformation remedied the non-normal distribution in these data. 


\begin{tabular}{|c|c|}
\hline & Description \\
\hline \multicolumn{2}{|c|}{ Dependent variables } \\
\hline INCREMENTAL & $\begin{array}{l}\text { Firm reported any innovations across size types that is new to the firm NOT new to the } \\
\text { industry, introduced within the last three years coded " } 1 \text { " yes, or " } 0 \text { " no. }\end{array}$ \\
\hline NOVEL & $\begin{array}{l}\text { Firm reported any innovations across size types that is new to the firm AND new to the } \\
\text { industry, introduced within the last three years coded " } 1 \text { " yes, or " } 0 \text { " no. }\end{array}$ \\
\hline PRODSERV & $\begin{array}{l}\text { Firm reported any product or service innovations in the last three years Coded " } 1 \text { " yes, or " } 0 \text { " } \\
\text { no. }\end{array}$ \\
\hline PROC & $\begin{array}{l}\text { Firm reported any Distribution, Process, Service Delivery or managerial innovation in the } \\
\text { last three years. Coded "1" yes, or "0" no. }\end{array}$ \\
\hline \multicolumn{2}{|c|}{ Independent variables } \\
\hline RED & $\begin{array}{l}\text { Factors have acted as a significant limitation or barrier on your ability to meet your business } \\
\text { objectives: Government regulations and compliance (red-tape). Likert scale value of } 4 \text { - very } \\
\text { significant limitation or higher encoded } 1 \text {. }\end{array}$ \\
\hline GREEN & Environmental compliance (green-tape) treated same as above. \\
\hline UNCERT & Environmental regulatory uncertainty treated same as above. \\
\hline STANDING & $\begin{array}{l}\text { Four variable construct with Cronbach Alpha of } .811 \text {. How would you rate your competitive } \\
\text { advantages on a scale } 1 \text { - Not a competitive advantage, } 5 \text { - key differentiator. See Table } 3\end{array}$ \\
\hline NETWORKING & $\begin{array}{l}\text { Three variable construct with Cronbach Alpha of .680. How would you rate your } \\
\text { competitive advantages on a scale } 1 \text { - Not a competitive advantage, } 5 \text { - key differentiator. See } \\
\text { Table } 3 \text {. }\end{array}$ \\
\hline COLLAB & Dummy for collaboration "1" - any, "0" none. \\
\hline \multicolumn{2}{|r|}{ - } \\
\hline RD_DUM & Dummy for conduct of R\&D “1”- any, "0" none. \\
\hline SERTICE & $\begin{array}{l}\text { Dummy for industry position, takes a value of " } 1 \text { " for all firms that are not oil and gas } \\
\text { operators, "0" if oil and gas operator. }\end{array}$ \\
\hline LOG_SIZE & Natural logarithm of size \\
\hline
\end{tabular}

\subsection{Qualitative data}

To provide contextual support for the models we also collected qualitative data. We chose our cases using purposive sampling to construct appropriate illustrative case studies to explore the relationships observed in the quantitative data. A theoretical sampling frame was developed to collect qualitative data consisting of three industry tiers: operators, contractors, and suppliers (Crabtree et al., 1997). Operators have legal responsibility for upstream oil and gas exploration and production and organise this work through a supply chain of consisting of contractors and service providers. Contractors work directly with operators (or sometimes under Engineering Procurement and Construction (EPC) contractors) and provide a range of services from drilling to construction and logistics. Finally, Suppliers include those who supply basic material goods up to specialised material / service providers. Examples include geotechnical services and land rehabilitation services.

Two sources of data were used to fill this theoretical frame. The first data source are papers presented at APPEA's Inaugural CSG conference held in Brisbane in October 2012. This was the first industry trade group conference specifically focused on CSG held in Australia. CSG projects represent over \$US 50b in infrastructure investment in Queensland (BCA, 2012). The second source of data was interviews conducted by the authors in 2012 
with executives firms operating in the Australian oil and gas industry. Selected interviews and presentations were transcribed from our larger set in order to fill the theoretical frame as appropriate (Table 5).

Table 5- Qualitative examples invoked in discussion section

\begin{tabular}{|c|c|c|c|c|}
\hline $\begin{array}{l}\text { Theoretical } \\
\text { frame level }\end{array}$ & Organisation & Type & Level & Topic \\
\hline \multirow[t]{2}{*}{ Operators } & Arrow Energy & $\begin{array}{l}\text { Conference } \\
\text { Transcripts }\end{array}$ & Project manager & $\begin{array}{l}\text { Brine management of coal seam gas } \\
\text { associated water }\end{array}$ \\
\hline & $\begin{array}{l}\text { GLNG Project, Santos } \\
\text { Limited }\end{array}$ & & Manager & $\begin{array}{l}\text { CSG water, benefits beyond the project } \\
\text { life-cycle }\end{array}$ \\
\hline \multirow[t]{2}{*}{ Contractors } & Cardno ENTRIX & & Executive & Beneficial reuse of CSG produced water \\
\hline & Murphy Pipe \& Civil & & Executive & $\begin{array}{l}\text { Gas and water pipeline construction and } \\
\text { installation }\end{array}$ \\
\hline Suppliers & Groundworks & Interview & Executive & Land rehabilitation, re-vegetation \\
\hline
\end{tabular}

\section{Analysis and Discussion}

\subsection{Findings}

First, we turn to the regulatory factors and the relationship to innovation. From the bivariate correlation matrix in Table 6 it can be seen that all three of the regulatory factors (RED, GREEN, UNCERT) are highly and positively correlated. However, the impact on innovation differs for each (Table 7). We find no significant relationship between innovation and general regulatory constraints (RED tape) or environmental regulatory uncertainty (UNCERT) in our models. However, environmental regulatory constraints (GREEN tape) relates positively to innovation. In fact, firms citing high GREEN tape are three times more likely to introduce novel innovations (any type, e.g. product, service and process) and nearly four times for products/services innovations (both novel and incremental). GREEN tape is not related to INCREMENTAL innovation or with firms' internal innovations (PROC).

Second, firm-level capabilities appear to relate strongly to innovation in models where environmental burden is high. In models where GREEN tape is high (the NOVEL and PRODSERV models), the construct we term STANDING is significant and positive. This means that technological breadth and depth, the ability to conduct projects and a strong reputation in tandem provide either the basis for dealing adeptly with environmental regulatory constraints, and perhaps supports the 'beyond compliance' hypothesis (Berkhout, 2014). Another capability-related construct, NETWORKING, is significant in the 
PRODSERV models and implies that latent relationships with supply chain partners support the development of new innovation. This insight is in line with the thinking of Kemp, et al., (2000), which posits that networks of firms coordinate to respond to the regulatory challenges in particular industries. The finding that this is most likely associated with firms operating at lower levels of the supply chain (e.g. are not oil and gas operators) is supported by research on the upstream oil and gas industry (Perrons and Donnelly, 2012) and other serviceenhanced industries like construction (Gann and Salter, 2000).

Third, maintaining formal collaborations and conducting $R \& D$ appears to be even more important to innovation than firm-level competitive capabilities in the models where environmental regulatory burden is high. Collaboration and $R \& D$ are both important in the PRODSERV and NOVEL models. The PRODSERV model implies that firms conducting $\mathrm{R} \& \mathrm{D}$ are, with high probability, capable of producing innovation in light of environmental regulatory constraints. Previous research suggests this is indicative of the absorptive capacity of a firm, that is, its potential to learn from external firm engagements (Cohen and Levinthal, 1990). In our context, we take this to mean that firms who do not conduct R\&D or engage in formal collaborations will lack the ability to meet the regulatory challenge and innovate, or moreover, will not see the competitive advantage of doing so (Berkhout, 2014).

Fourth, the industry control variable reveals that PRODSERV innovations are not related to industry position. This means the relationships between environmental regulations, capabilities, collaboration and $\mathrm{R} \& \mathrm{D}$ are robust and apply to the entire supply chain which is an important finding. In contrast, NOVEL, INCREMENTAL and PROC are most likely to be SERVICE firms (not oil and gas operators). 
Table 7 - Logistic Regression Results $(\mathrm{N}=\mathbf{8 0})$

\begin{tabular}{|c|c|c|c|c|c|c|c|c|}
\hline & NOVEL & & INCREMENTAL & & PRODSERV & & PROC & \\
\hline & Odd & sig & Odd & sig & Odd & sig & Odd & sig \\
\hline RED & 0.91 & & 1.59 & & 1.42 & & 0.98 & \\
\hline GREEN & 3.18 & $*$ & 1.09 & & 3.93 & * & 1.59 & \\
\hline UNCERT & 0.60 & & 0.86 & & 0.48 & & 1.50 & \\
\hline STANDING & 2.03 & $* *$ & 1.39 & & 1.83 & $* *$ & 1.54 & $*$ \\
\hline NETWORKING & 1.43 & & 3.29 & $* * *$ & 1.53 & $*$ & 1.89 & $* *$ \\
\hline COLLAB & 3.11 & $* *$ & 2.11 & & 4.58 & $* *$ & 0.75 & \\
\hline $\mathrm{RD}$ & 6.61 & $* * *$ & 4.43 & $* * *$ & 11.31 & $* * *$ & 2.32 & $*$ \\
\hline SERVICE & 2.72 & $*$ & 2.95 & $*$ & 1.44 & & 3.21 & $* *$ \\
\hline LOG_SIZE & 1.00 & & 0.72 & $* *$ & 0.77 & $* *$ & 1.08 & \\
\hline Chi-square & 29.459 & & 25.419 & & 29.443 & & 15.288 & \\
\hline df & 9 & & 9 & & 9 & & 9 & \\
\hline Sig. & .001 & & .003 & & .001 & & .083 & \\
\hline Nagelkerke R Square & .420 & & .371 & & .422 & & .252 & \\
\hline
\end{tabular}

\subsection{Exploring the model results through examples}

This section uses contextual examples from the Australian oil and gas industry to explore the links between innovation, capabilities, collaboration and environmental burden found in the models. In particular we aim to provide regulatory framework nuance that our models cannot. First, we look toward the CSG to LNG industry in Queensland, Australia, where we review produced water challenge the industry faces. Second, we provide a summary of the emerging CSG produced water environmental regulatory regime. Third, we explore the potential implications of these policies on innovation. Fourth, we examine specific examples of innovation examples within this context.

Although we use Queensland CSG innovation examples to contextualise our model results, it is important to remember the models reflect both conventional and unconventional oil and gas and represent firms from all regions of Australia. Over half of sample consists of firms headquartered in Western Australia, and over a third report conventional oil and gas interests. Further, we know of similar environmentally related innovation occurring in conventional gas developments. Two examples from the US\$52 billion dollar Gorgon gas development project by Chevron on Barrow Island, Western Australia help prove this point. First, LNG production trains have completely modularised for the first time on such scale to minimise footprint and disturbance of the land - a world first. Second, a purpose-built, award-winning quarantine management system that decontaminates equipment, modules and 
staff has been developed to maintain the island's 'class A' nature reserve status (UNAA, 2012).

\subsubsection{The CSG produced water challenge}

The Australian CSG industry must treat significant volumes of produced water containing metals and large quantities of saline produced during operations (Nghiem et al., 2011). CSG wells can produce water for up to 15 years (Nghiem et al., 2011), requiring long term solutions to this large-scale challenge. Salinity levels are high in this produced water, exceeding waste water discharge levels. For example, at Arrow Energy's Surat Basin operations water salinity can reach upwards of 5,000 parts per million (ppm), well above the acceptable water use level of 1,000ppm (Sherriff, 2012). Over the 20 to 40 year life cycle of Arrow's CSG operations, they estimate $2-2.5 \mathrm{M}$ tonnes of salt will be produced with daily peaks of 400-500 tonnes per day and averaging around 200 tonnes of salt per day (Sherriff, 2012).

\subsubsection{CSG water regulation and policy}

Unlike most Australian states that regulate produced water purely as a waste, Queensland Government is treating produced water as a resource to be strategically managed (Tormey, 2012). The Coal Seam Gas Water Management Policy published by Queensland Government "encourages the beneficial use of CSG water in a way that protects the environment and maximises its productive use as a valuable resource disposal (Queensland Government, 2012a, p.1)". The document prioritises beneficial reuse for the environment, existing or new water users or new water dependent industries over treatment and disposal. For the brine byproduct, the Government supports the development of useable products over disposal.

The Queensland Government's Approval of Coal Seam Gas Water for Beneficial Use guidelines promote "beneficial use" options that work within the existing regulatory framework. The policy "does not specify treatment standards or methods; rather indicates criteria to be met for the use of CSG water" for particular beneficial use options (Queensland Government, 2012b, p. 4). The Coal Seam Gas Water Management Policy however, also outlines outstanding regulatory changes the Government intends to make that will ensure beneficial use projects are likely to be undertaken by industry (Queensland Government, 2012a). These future actions include amending the 1994 Environmental Production Act with new CSG water quality standards to avoid classification as a regulated waste, to reduce 
duplication of regulation stemming from the Water Supply Act of 2008 and to develop clear standards for CSG water irrigation schemes (Queensland Government, 2012a).

\subsubsection{Policy implications on innovation}

Faced with the produced water challenge but guided by policy that encourages water and salt reuse, firms in the CSG sector of Queensland are undertaking considerable investment to develop technological solutions. A report by the GasFields Commission Queensland found 188 CSG water-related science and research projects either completed or underway (as of October 2012) that directly link to the Queensland CSG sector (Raine, 2012). The majority of these projects are focused on groundwater hydrology. The second most frequent research area was surface water management including produced water treatment, discharge and reuse efforts like irrigation (Raine, 2012).

\subsubsection{Illustrative case study examples of innovation}

Against the background of the CSG produced water challenge and seemingly favorable regulatory context, we explore specific examples of innovation. The following paragraphs elaborate upon several qualitative examples that support the empirical findings summarised in Table 8. 
Table 8- Illustrative case study examples and linkage to findings

\begin{tabular}{|c|c|c|c|c|c|}
\hline $\begin{array}{l}\text { Theoretical } \\
\text { frame }\end{array}$ & Organisation & Innovation Summary & $\begin{array}{l}\text { Link to } \\
\text { dependent } \\
\text { variables } \\
\end{array}$ & $\begin{array}{l}\text { Link to } \\
\text { independent } \\
\text { variables } \\
\end{array}$ & $\begin{array}{l}\text { Links to } \\
\text { Controls }\end{array}$ \\
\hline \multirow[t]{2}{*}{ Operators } & Arrow Energy & $\begin{array}{l}\text { Development of CSG water } \\
\text { treatment with salt and carbonate } \\
\text { recovery systems }\end{array}$ & $\begin{array}{l}\text { PRODSERV, } \\
\text { NOVEL }\end{array}$ & $\begin{array}{l}\text { GREEN, } \\
\text { STANDING** }\end{array}$ & R\&D \\
\hline & $\begin{array}{l}\text { GLNG Project, } \\
\text { Santos Limited }\end{array}$ & $\begin{array}{l}\text { First CSG agricultural irrigation } \\
\text { pilot operation, and continued } \\
\text { development of technology and } \\
\text { beneficial use applications } \\
\text { including livestock watering }\end{array}$ & $\begin{array}{l}\text { PRODSERV, } \\
\text { NOVEL }\end{array}$ & $\begin{array}{l}\text { GREEN; } \\
\text { STANDING** }\end{array}$ & $\mathrm{R} \& \mathrm{D}$ \\
\hline \multirow[t]{2}{*}{ Contractors } & $\begin{array}{l}\text { Cardno } \\
\text { ENTRIX }\end{array}$ & $\begin{array}{l}\text { Tailored water recycle and } \\
\text { beneficial use engineering } \\
\text { services for CSG operators and } \\
\text { R\&D for heat recovery from } \\
\text { groundwater }\end{array}$ & $\begin{array}{l}\text { PRODSERV, } \\
\text { NOVEL }\end{array}$ & $\begin{array}{l}\text { GREEN, } \\
\text { COLLAB }\end{array}$ & $\begin{array}{l}\text { SERVICE*, } \\
\text { R\&D }\end{array}$ \\
\hline & $\begin{array}{l}\text { Murphy Pipe \& } \\
\text { Civil }\end{array}$ & $\begin{array}{l}\text { Rapid gas and water pipeline } \\
\text { construction and installation using } \\
\text { an adapted German } \\
\text { telecommunication ploughing } \\
\text { technology }\end{array}$ & $\begin{array}{l}\text { PRODSERV; } \\
\text { NOVEL }\end{array}$ & $\begin{array}{l}\text { GREEN, } \\
\text { COLLAB }\end{array}$ & $\begin{array}{l}\text { SERVICE*, } \\
\text { R\&D }\end{array}$ \\
\hline Suppliers & Groundworks & $\begin{array}{l}\text { Land rehabilitation, re-vegetation } \\
\text { through in-licensed technology } \\
\text { adapted to grow trees }\end{array}$ & $\begin{array}{l}\text { PRODSERV, } \\
\text { NOVEL }\end{array}$ & $\begin{array}{l}\text { GREEN, } \\
\text { COLLAB }\end{array}$ & $\begin{array}{l}\text { SERVICE*, } \\
\text { R\&D }\end{array}$ \\
\hline
\end{tabular}

*refers to the industry control variable indicating this firm is NOT an oil and gas operator

** Example appears to be internal sourced/managed project to our knowledge thus would appear breadth/depth of technical expertise, reputation, are important factors

Arrow Energy undertook a lengthy study of CSG water management practices for their operations in the Surat Basin. Arrow evaluated several technology-driven scenarios for beneficial reuse that included capital investment, project life operating costs and abandonment costs and non-economic criteria such as ease of resource recovery, land impact, constructability and greenhouse gas emissions. Arrow found that traditional options like evaporation ponds are becoming dearer, due to the environmental regulatory constraints including pond linings, environmental monitoring and abandonment costs including soil characterisation and potential remediation costs (Tormey, 2012). Also, the Surat Basin is located far from the ocean precluding brine discharge options. It is also not conducive geologically for brine injection, although the most economically appealing solution.

Ultimately Arrow's analysis identified selective salt recovery technology as the preferred solution (Sherriff, 2012). Although simple salt recovery options are readily available and technologically feasible, recovering carbonates - another by-product in the Surat Basin - in addition to chloride salts would reap significant economic benefits if efficiencies of scale can be achieved. Arrow continues to pursue this most technologically 
complex and energy intense reuse option, recognising it is also a preferred option in the view of the regulators (Sherriff, 2012).

Santos is using CSG-produced water to improve the regional agricultural through crop irrigation. Santos developed a drip irrigation system, the first such application of CSG water irrigation in Australia, called the Mount Hope Pilot and continues to trial new and improved pilot test systems. Their GLNG project is estimated to produce around 340 giga-litres of water, $200-250$ giga-litres of which will be utilised for irrigation to re-establish native landscapes and as water for livestock in the Fairview and Arcadia Valley geographic regions (Davidge, 2012).

Cardno ENTRIX, an environmental and water engineering consultancy, is playing an active role in the effort to optimize technical solutions for Queensland's CSG operators. On the exploratory side of research, Cardno is investigating geothermal energy production and waste heat recovery technology relating to coal seam and shale gas in collaboration with United States Department of Energy National Renewable Energy Laboratory (NREL) (Tormey, 2012). On engineering related efforts, Cardno is working directly with Australian firms following a three-step CSG water management framework to optimise energy usage and water volume reduction. First, characterisation of the basin-specific produced water quality must be undertaken. Second, identification of beneficial uses must be conducted. Third, matching treatment technologies with source characteristics and the quality requirement of beneficial uses thus optimising the technology to the overall dynamics of the field (Tormey, 2012).

Murphy Pipe and Civil has adapted a German ploughing technology used to bury telecommunications and power cables into one that lays large diameter high density polyethylene (HDPE) pipe (Campbell, 2012) going beyond the simple regulatory stipulation that pipelines must be buried (Rennie, 2013). There are direct environmental benefits associated with Murphy's plough because it minimises the disturbance of top soil compared to traditional trenching operations. As the managing director recalled in his speech "there's no mixing of subterranean soils so the plough basically lifts the soil and goes back down. There is no churning or excavation" (Campbell, 2012). The plough actually inserts pipe as it moves forward, allowing the pipe to stay in place. It can operate with only ten metre easements (compared with 30 to 50 metres in other methods) and can lay up to ten kilometres of pipe in a single day. Guided by GPS, the system also helps minimise rework on the pipe once laid. To develop this innovation Murphy worked with one of the industry CSG operators 
to re-design the machine to suit the operating requirements in Australia, incorporating over 90 changes since 2009 (Campbell, 2012).

Another environmental implication of CSG is the quantity of produced water that will far exceed demands for beneficial use (Nghiem et al., 2011), and will temporarily need captured in large holding ponds. Once built, these holding ponds are typically sowed with grass to secure their earthen embankments. This approach, according to Groundworks Pty CEO Tony Rees, performs poorly because typical grasses applied to the relatively acidic soils in parts of Queensland leads to poor root structure development. Thus, holding ponds treated in this manner require considerable upkeep, and in some cases embankments must be rebuilt when damaged by heavy rains (Rees, personal communication).

To address this challenge Groundworks developed a one-time application of a modified Ecoblanket ${ }^{\circledR}$ product which quickly ensconces native trees and shrubs that have better root structures than grass alone. As the sole licensee of the technology in Australia and New Zealand, Groundworks enhanced this erosion control / re-vegetation technology to incorporate native seed mixtures containing grass, tree and shrub species which are tolerant to the high saline and acidic nature of Australian soils. Tony claims his product represents a marked improvement over normal methods, describing "completely stabilised ground cover within a couple of weeks and full cover with secondary species coming through after the cover crop in about six weeks. And it's completely stable." Groundworks has applied this product on several CSG ponds embankments in Queensland (Rees, personal communication).

Groundworks also collaborated with the UniQuest, a research commercialisation company co-located at The University of Queensland, to justify Ecoblanket ${ }^{\circledR}$ as a carbon offset method (Rees, personal communication). They found that re-vegetation including trees and shrubs based on the adapted Ecoblanket ${ }^{\circledR}$ technology produces 50 per cent more carbon sequestration than a normal planted forest. Based on these data, Groundwork's filed to expand the current eligibility definitions within the of Australia's Department of Climate Change and Energy Efficiency's Carbon Farming Initiative (CF) to include forest established through direct seeding, planting or via spreading of Ecoblanket ${ }^{\circledR}$ (Rees, personal communication).

On the one hand, the aforementioned CSG water innovations are perhaps a reflection of the collaborative, outcome-focused regulatory environment. On the other hand, it can be argued these examples show firms striving to make their operations very environmentally robust and going beyond compliance. For instance, Arrow is pursuing selective salt recovery which requires a significant investment in $R \& D$ to develop the process to achieve economies 
of scale necessary to make the investment in the plant positive. Santos is striving to use water in the agriculture arena, tangentially supporting another important Australian industry and making it more sustainable in the process. Murphy Pipe and Civil's pipeline burying technology, though not mandated to do so, minimises land disturbance and loss of topsoil. Groundwork's process to grow trees from a single initial application of Ecoblanket may soon be approved to qualify for carbon offsets.

Together these examples appear to reflect the propensity of firms to go beyond compliance in order to garner competitive advantage by bolstering social license. As Tony Ree's laments, firms in the industry should all strive to exceed expectations on the social front, by returning the land to its original state. He says CSG firms should all strive to "give back to the community in the appropriate manner, you have less headaches, less costs, better engagement and you're doing the right thing for the environment, as well as developing an economic model that's benefiting the State, individual and communities. That's the way it should been seen. Rehab shouldn't be a dirty word."

\section{Conclusions}

On a basic level we find some support for the original version of Porter Hypothesis and its top-down view that regulation spurs innovation. Using a representative cross section of the entire upstream oil and gas industry of Australia, we find that firms faced with high levels of regulatory burden are more likely to introduce product and service innovations, as well as innovations that are both new-to-the-industry and new-to-the-firm (i.e. novel).

In an effort to contextualise this finding, we explored illustrative examples of innovations in the CSG industry and found some support that more collaborative regulation can help spur innovation. Our tentative evidence suggests that the less prescriptive nature of the regulatory approach taken by the Queensland government is supporting innovation. For example, the Queensland's GasFields Commission report demonstrates high levels of CSG R\&D activity (Raine, 2012), which we believe trumps alternative explanations such as industrial competitiveness regulations (Harrison, 1999, p. 53). We see evidence of innovation in our illustrative examples, from Arrow Energy and Santos efforts to develop salt and soda ash recovery technologies and beneficial reuses options for water, to Cardno ENTRIX support to multiple operators to develop similar technological solutions. Meanwhile, Murphy Pipe and Civil created a machine that buries 18" HDPE pipe continuously with minimal environmental impact from a German plough that formerly buried electric cable. Finally, 
Groundworks has innovated upon a licensed technology, Ecoblanket ${ }^{\circledR}$, to grow trees and shrubs on CSG pond embankments where others only have planted grass, and is pursuing carbon offset accreditation.

However, our findings go well beyond the top-down view which prioritises regulation intensity and type, and we find compelling evidence that the relationship between regulation and innovation is complex and firm-level competitive factors exert influence. We recognise that firms in increasing numbers over comply with regulation to gain competitive advantage and to maintain social license to operate (remain socially acceptable to active and wellinformed stakeholders) (Berkhout, 2014). Therefore innovation might reflect the propensity of firms go beyond compliance, in a more bottom-up perspective which is some ways preemptive to regulation. To explore this relationship our models included firm-level factors relating to capability. We found product / service and novel innovations are simultaneously related to high regulatory burden and the presence of competitive capabilities, collaborative activity and R\&D. Thus, it is the presence of all of these factors in tandem which explain innovation in this industry according to our models. Our illustrative case studies also support the close ties between innovation and internal capabilities (including R\&D and collaboration).

The finding that competitive capabilities relate to innovation in the face of regulatory burden is a very important empirical contribution to the literature on over-compliance as strategy (e.g. Berkhout, 2014). One interpretation of this finding is that firms with strong capabilities, when faced with tough environmental regulation, have the capacity to innovate in response. However, a more compelling interpretation of this finding is found in contemporary literature on how firms over-comply as a competitive strategy by garnering technological advantage over competitors (Innes and Bial, 2002; Wu, 2009) and bolstering social license to operate (Berkhout, 2014; Gunningham, 2004; Sarker 2013). The construct we find important in this regard is comprised of the breadth and depth of technological expertise, project management performance and a strong reputation. Increasing technological breadth and depth would appear to support the notion of garnering advantage over competitors by innovating in an environmental manner, while performing well on project (which as discussed this industry has a very high environmental interface) all the while maintaining a sterling reputation, appears to reflect issues of social license. Our crosssectional study limits our ability to reveal comment on directionality of these relationships and future research should strive to capture longitudinal effects in this regard. 
Playing an even more important role than competitive aspects in delivering innovation in the face of regulatory burden is external collaboration. Because our models are based upon a representative cross section of an industry supply chain, this finding reveals important empirical evidence of network affects, as firms organise into collaborations to deliver innovative solutions and respond to regulation. Further, while we see industry segmentation in the development of novel innovations (this is in the realm of suppliers rather than oil and gas operators) we see no such distinction in terms of product and service innovations. This latter finding in particular provides further evidence that the development of these important types of innovation is through a process of negotiation across the levels of the supply chain network (Gann and Salter, 2000; Kemp et. al., 2000).

\section{Acknowledgements}

Funding for this research was provided by a grant from The University of Queensland Collaboration and Industry Engagement Fund (CIEF) and funds from the UQ Centre for Coal Seam Gas. We also acknowledge in-kind support and financial assistance from Ernst \& Young (EY). We are grateful to the Australian Petroleum Production and Exploration Association (APPEA) for facilitating access to its membership for the conduct of the survey. Last, but certainly not least, the authors would like to thank Jamie L. Ford for her research and editorial services. 


\section{Bibliography}

(UNAA - United Nations Association of Australia Victorian Division), 2012. WINNER:

Chevron Australia - Barrow Island Quarantine Management System [WWW

Document]. BHP Billiton Business Awards Environmental best practice program. URL http://www.unaavictoria.org.au/awards-programs/world-environment-dayawards/winners-finalists/ (accessed 2.19.13).

ABC, 2012. Coal Seam Gas: By The Numbers (Australian Broadcasting Corporation) [WWW Document]. ABC news On-line. URL http://www.abc.net.au/news/specials/coal-seam-gas-by-the-numbers/ (accessed 7.3.12).

Ambec, S., Cohen, M.A., Elgie, S., Lanoie, P., 2011. The Porter Hypothesis at 20: Can Environmental Regulation Enhance Innovation and Competitiveness?

Baruch, Y., 1999. Response Rate in Academic Studies-A Comparative Analysis. Human Relations 52, 421-438.

BCA, 2012. Pipeline or Pipe Dream? Securing Australia's Investment Future. Melbourne.

Berkhout, F., 2014. Innovation and Sustainability, in: Dodgson, M., Gann, D., Phillips, N. (Eds.), Oxford Handbook of Innovation Management. Oxford University Press, Oxford.

Brunnermeier, S.B., Cohen, M.A., 2003. Determinants of environmental innovation in US manufacturing industries. Journal of Environmental Economics and Management 45, 278-293.

Campbell, J., 2012. How HDPE innovations are delivering beneficial outcomes to the CSG industry, in: APPEA CSG Conference \& Exihibition. Australian Petroleum Production and Exploration Association, Brisbane, p. n/a.

Christainsen, G., Haveman, R., 1981. The Contribution of Environmental-Regulations to the Slowdown in Productivity Growth. Journal of Environmental Economics and Management 8, 381-390.

Cohen, W.M., Levinthal, D.A., 1990. Absorptive Capacity: A New Perspective on and Innovation Learning. Administrative Science Quarterly 35, 128-152.

Cosh, A., Fu, X., Hughes, A., 2012. Organisation structure and innovation performance in different environments. Small Business Economics 39, 301-317.

Crabtree, E., Bower, D.J., Keogh, W., 1997. Conflict or collaboration: the changing nature of inter-firm relationships in the UK Oil and Gas industry. Technology Analysis \& Strategic Management 9, 179-192.

Damanpour, F., 1991. Organizational Innovation: A Meta-Analysis of Effects of Determinants and Moderators. The Academy of Management Journal 34, 555-590. 
Davidge, S., 2012. CSG Water - sustaining benefits beyond the project life-cycle, in: APPEA CSG Conference \& Exihibition. Australian Petroleum Production and Exploration Association, Brisbane, p. n/a.

De Villiers, C., van Staden, C.J., Villiers, C. De, Staden, C.J. Van, 2010. Shareholders' requirements for corporate environmental disclosures: A cross country comparison. The British Accounting Review 42, 227-240.

Freeman, A., Haveman, R., 1972. Residuals Charges for Pollution-Control - Policy Evaluation. Science 177, 322-329.

Gann, D.M., Salter, A.J., 2000. Innovation in project-based, service-enhanced firms: the construction of complex products and systems. Research Policy 29, 955-972.

Gunningham, N., Kagan, R. a., Thornton, D., 2004. Social License and Environmental Protection: Why Businesses Go Beyond Compliance. Law and Social Inquiry 29, $307-$ 341.

Hair, J.F., Anderson, R.E., 2010. Multivariate data analysis. Prentice Hall.

Harrison, K., 1999. Talking with the Donkey: Cooperative Approaches to Environmental Protection. Journal of Industrial Ecology 2, 51-72.

Harrison, K., 2002. Ideas and environmental standard-setting: A comparative study of regulation of the pulp and paper industry. Governance-an International Journal of Policy and Administration 15, 65-96.

Hascic, I., Johnstone, N., Michel, C., 2008. Environmental policy stringency and technological innovation: Evidence from patent countsll, in: European Association of Environmental and Resource Economists 16th Annual Conference, Gothenburg, Sweden.

Innes, R., Bial, J.J., 2002. Inducing Innovation in the Environmental Technology of Oligopolistic Firms. The Journal of Industrial Economics 50, 265-287.

Jaffe, A.B., Newell, R.G., Stavins, R.N., 2005. A tale of two market failures: Technology and environmental policy. Ecological Economics 54, 164-174.

Jaffe, A.B., Palmer, K., 1997. Environmental Regulation and Innovation: A Panel Data Study. The Review of Economics and Statistics 79, 610-619.

Kemp, R., Smith, K., Becher, G., 2000. How should we study the relationship between environmental regulation and innovation? European Commission DG JRC, Sevilla.

Köhler, C., Sofka, W., Grimpe, C., 2012. Selective search, sectoral patterns, and the impact on product innovation performance. Research Policy 41, 1344-1356.

Lange, I., Bellas, A., 2005. Technological Change for Sulfur Dioxide Scrubbers under Market-Based Regulation. Land Economics 81, 546-556. 
Lanjouw, J.O., Mody, A., 1996. Innovation and the international diffusion of environmentally responsive technology. Research Policy 25, 549-571.

López-Gamero, M.D., Molina-Azorín, J.F., Claver-Cortés, E., 2010. The potential of environmental regulation to change managerial perception, environmental management, competitiveness and financial performance. Journal of Cleaner Production 18, 963-974.

Managi, S., Opaluch, J.J., Jin, D., Grigalunas, T.A., 2005. Environmental Regulations and Technological Change in the Offshore Oil and Gas Industry. Land Economics 81, 303319.

Newell, R.G., Jaffe, A.B., Stavins, R.N., 1999. The Induced Innovation Hypothesis and Energy-Saving Technological Change. The Quarterly Journal of Economics 114, 941975.

Nghiem, L.D., Ren, T., Aziz, N., Porter, I., Regmi, G., 2011. Treatment of coal seam gas produced water for beneficial use in Australia: A review of best practices. Desalination and Water Treatment 32, 316-323.

OECD, 2005. Oslo Manual: Guidelines for Collecting and Interpreting Innovation Data, 3rd ed, Communities. Organisation for Economic co-operation and Development, Statistical office of the European Communities, Luxembourg.

Pellegrino, C., Lodhia, S., 2012. Climate change accounting and the Australian mining industry: exploring the links between corporate disclosure and the generation of legitimacy. Journal of Cleaner Production 36, 68-82.

Perrons, R.K., Donnelly, J., 2012. Who Drives E\&P Innovation? Journal of Petroleum Technology 64, 62-72.

Popp, D., 2006. International innovation and diffusion of air pollution control technologies: the effects of NOX and SO2 regulation in the US, Japan, and Germany. Journal of Environmental Economics and Management 51, 46-71.

Popp, D., Newell, R.G., Jaffe, A.B., 2009. Energy, the Environment, and Technological Change.

Porter, M.E., 1991. America’s Green Strategy. Scientific American 264, 168-168.

Porter, M.E., van der Linde, C., 1995. Toward a New Conception of the EnvironmentCompetitiveness Relationship. The Journal of Economic Perspectives 9, 97-118.

Purvis, A., Outlaw, J., 1995. What We Know about Technological Innovation to Achieve Environmental Compliance: Policy Issues for an Industrializing Animal Agriculture Sector. American Journal of Agricultural Economics 77, 1237-1243.

Qi, G.Y., Shen, L.Y., Zeng, S.X., Jorge, O.J., 2010. The drivers for contractors' green innovation: an industry perspective. Journal of Cleaner Production 18, 1358-1365.

Queensland Government, 2012a. Coal Seam Gas Water Management Policy. Brisbane. 
Queensland Government, 2012b. Approval of coal seam gas water for beneficial use. Bribane.

Raine, S., 2012. Collation of Water-Related Science and Research Activities in the Queensland Coal Seam Gas Sector.

Rees, T., 2012. Personal Communication, Groundworks CEO Interview.

Rennie, M. (McKinsey \& C.A., 2013. Australian LNG: Pathways to productivity, in: APPEA Conference \& Exhibition. Australian Petroleum Production and Exploration Association, Brisbane.

Sarker, T.K., 2013a. Voluntary codes of conduct and their implementation in the Australian mining and petroleum industries : is there a business case for CSR ? 205-224.

Sarker, T.K., 2013b. Voluntary codes of conduct and their implementation in the Australian mining and petroleum industries: is there a business case for CSR? Asian Journal of Business Ethics 2, 205-224.

Scott, W.R., Levitt, R., Orr, R.J., 2011. Global Projects: Institutional and Political Challenges. Cambridge University Press.

Sharma, S., 2001. Different strokes: regulatory styles and environmental strategy in the North-American oil and gas industry. Business Strategy and the Environment 10, 344 364.

Sherriff, S., 2012. Brine Management of coal seam gas associated water: the Arrow Energy context, in: APPEA CSG Conference \& Exihibition. Australian Petroleum Production and Exploration Association, p. n/a.

Tormey, D.D., 2012. Optimisation approach to beneficial reuse of CSG produced water, in: APPEA CSG Conference \& Exihibition. Australian Petroleum Production and Exploration Association (APPEA), Brisbane, p. n/a.

Triebswetter, U., Hitchens, D., 2005. The impact of environmental regulation on competitiveness in the German manufacturing industry - a comparison with other countries of the European Union. Journal of Cleaner Production 13, 733-745.

Wu, J., 2009. Environmental compliance: The good, the bad, and the super green. Journal of Environmental Management 90, 3363-3381.

Yabar, H., Uwasu, M., Hara, K., 2013. Tracking environmental innovations and policy regulations in Japan: case studies on dioxin emissions and electric home appliances recycling. Journal of Cleaner Production 44, 152-158. 